\title{
Ekspor Sampah Uni Eropa Ke Indonesia Sebagai Bentuk Eco-Imperialism
}

\author{
Meyfitha Dea Khairunnisa \\ Universitas Indonesia
}

\begin{abstract}
Environmental policy has become an important aspect of reviewing international relations environmental issues. The European Union is a regional institution that has been very active in international environmental cooperation. However, at the same time, the European Union is one of the largest waste exporters to countries in Asia, including Indonesia. Waste export is a free trade mechanism that allows developed countries to send waste to developing countries to be processed as industry materials. This then becomes contradictory to the commitment of the European Union in promoting environmentally friendly policies, and policies for the export of waste are considered as a form of ecoimperialism. This article discusses how the waste export policy by the European Union has become a form of ecological colonization for Indonesia as a waste recipient.
\end{abstract}

Keywords: waste export; eco-imperialism; environmental policy

\begin{abstract}
ABSTRAK
Kebijakan lingkungan telah menjadi aspek penting dalam meninjau isu lingkungan dalam dimensi Hubungan Internasional. Uni Eropa merupakan institusi regional yang sangat aktif dalam kerjasama lingkungan internasional. Akan tetapi, Uni Eropa merupakan salah satu negara yang melakukan ekspor limbah terbesar ke Asia, termasuk Indonesia. Ekspor limbah ke negara berkembang akan diproses sebagai bahan industry. Hal ini telah menjadi isu yang kontradiktif dengan komitmen Uni Eropa terhadap mempromosikan kebijakan ramah lingkungan dan kebijakan terhadap ekspor limbah dinilai sebagai bentuk eco-imperialism. Artikel ini mendiskusikan tentang bagaimana kebijakan ekspor limbah oleh Uni Eropa telah menjadi bentuk kolonialisasi ekologi terhadpa Indonesia selaku penerima limbah.
\end{abstract}

Kata kunci: ekspor limbab; eco-imperialism; kebijakan lingkungan

\section{PENDAHULUAN}

Isu lingkungan menjadi salah satu isu yang diperhatikan dalam hubungan internasional. Hal ini dikarenakan peningkatan aktivitas manusia menyebabkan kerusakan lingkungan yang terjadi secara global dan masif. Salah satu permasalahan yang menjadi fokus internasional adalah perubahan iklim (climate change). Perubahan iklim didefinisikan sebagai perubahan yang terjadi terhadap iklim yang secara langsung maupun tidak langsung dikaitkan dengan kegiatan manusia yang mengubah komposisi atmosfer secara global dan keberagaman iklim alami yang terjadi diamati secara periodik (UNFCCC, 1992).

Salah satu faktor yang mempercepat perubahan iklim adalah adanya pemanasan global, sementara pemanasan global sendiri terjadi salah satunya adalah karena adanya peningkatan gas rumah kaca khususnya karbon dioksida (CO2). Karbon dioksida secara 
alami sudah ada di bumi selama ratusan ribu tahun dan jumlahnya di atmosfer stabil. Namun, perubahan ekstrem terjadi seiring dengan terjadinya Revolusi Industri. Peningkatan karbon dioksida mulai terjadi karena adanya peningkatan aktivitas manusia berupa pembakaran bahan bakar fosil (Ritchie \& Roser, 2019).

Gambar 1 Data Emisi Karbon Dunia per Tahun 2017.

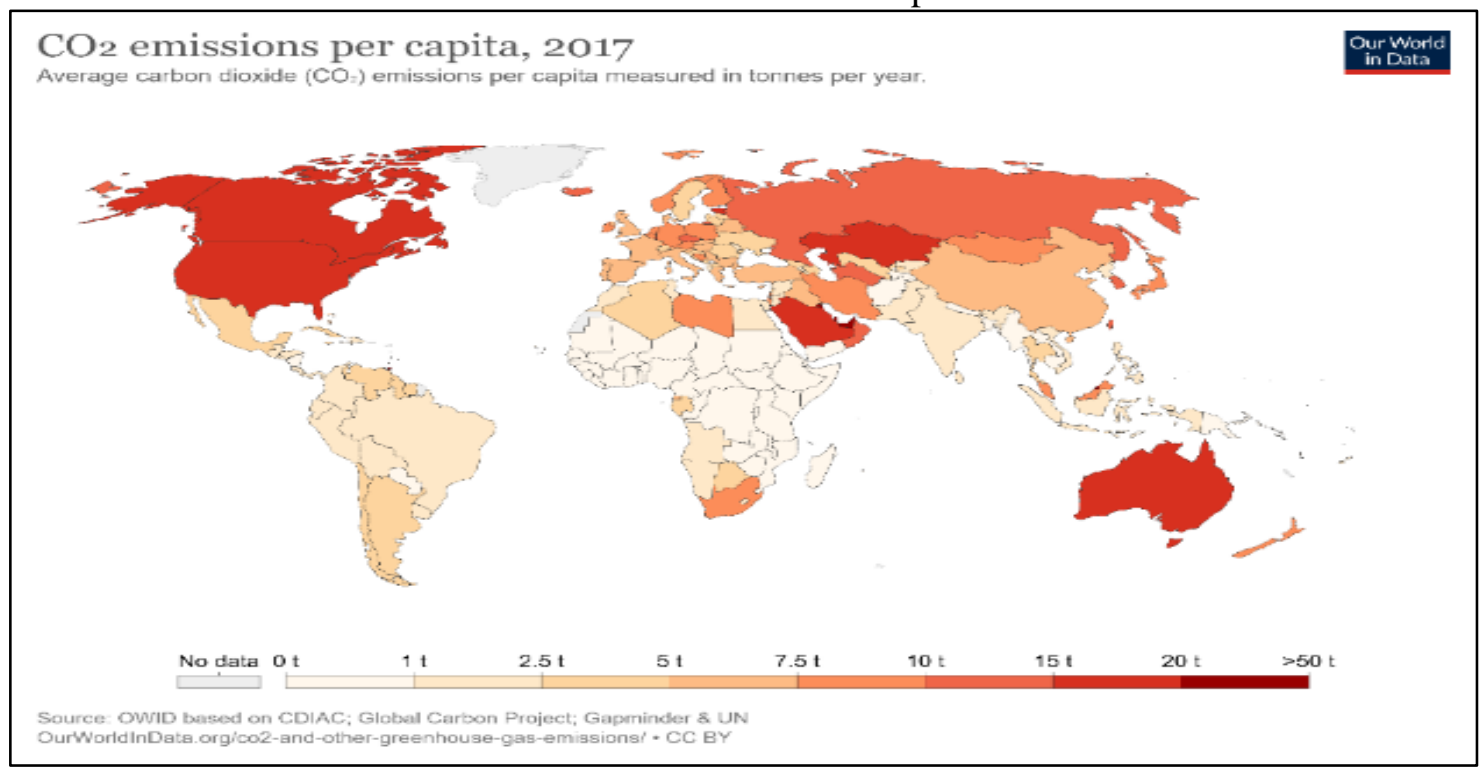

Sumber: Ritchie \& Roser, 2019

Urgensi isu lingkungan mendorong pembentukan UNFCCC (United Nations Framework Convention on Climate Change). Salah satu tujuan dibentuknya UNFCCC adalah agar anggota konvensi tersebut turut berpartisipasi untuk menstabilkan tingkat gas rumah kaca. Upaya awal yang dilakukan dalam memperlambat pemanasan global adalah dengan pembentukan Agenda 21. Agenda 21 merupakan acuan untuk pembangunan internasional berkelanjutan yang ramah lingkungan. Untuk mendukung Agenda 21 tersebut, berbagai kerja sama multilateral pun dilakukan. Salah satu bentuk kerja sama paling awal dalam mitigasi perubahan iklim adalah Kyoto Protocol yang diresmikan pada tahun 1997. Kyoto Protocol memiliki tujuan agar negara-negara anggotanya, khususnya negara-negara maju, berpartisipasi dalam mengurangi emisi karbon dengan cara menentukan target yang mengikat (UNFCCC, 2019).

Dalam Kyoto Protocol, negara-negara anggota dibebaskan untuk menjalankan berbagai kebijakan untuk mencapai target yang ditentukan. Meskipun Kyoto Protocol menekankan pencapaian target melalui upaya yang bersifat nasional, Kyoto Protocol juga menawarkan negaranegara tersebut untuk melakukan tiga mekanisme berbasis pasar, yakni clean development mechanism (CDM), joint implementation (JI), dan emission trading (ET). Selain itu, terdapat juga Basel Convention yang mengatur pencegahan pergerakan bahan-bahan berbahaya yang terdapat dalam sampah dan limbah.

Uni Eropa merupakan satu-satunya institusi regional yang menjadi anggota dalam Kyoto Protocol dan Basel Convention. Keanggotaan Uni Eropa dalam Kyoto Protocol bersifat Annex I yang berarti negara-negara dalam kategori tersebut termasuk sebagai negara-negara industri yang pernah menjadi bagian dari OECD (Organisation for Economic Co-operation and Development). Namun, di balik partisipasi Uni Eropa dalam kebijakan lingkungan, salah satu 
kebijakan yang dilakukan Uni Eropa adalah ekspor sampah ke negara-negara Asia. Sampah ini dikirimkan oleh Uni Eropa dengan tujuan untuk didaur ulang di negara-negara tujuan. Mekanisme ini sering disebut juga sebagai global waste trade.

Meskipun sudah ada regulasi mengenai jenis sampah yang bisa diekspor, regulasi tersebut tidak mampu mencegah adanya unsur bahan berbahaya dan beracun (B3) yang masih terkandung dalam sampah. Selain itu, terdapat sampah material yang tidak bisa didaur ulang seperti beberapa jenis plastik. Pada tahun 2017, Cina sebagai negara pengimpor sampah terbesar memutuskan untuk berhenti mengimpor 24 jenis sampah dan kebijakan tersebut berlaku sejak tahun 2018 (Lee, 2018).

Hilangnya Cina sebagai negara tujuan ekspor sampah menjadikan negara-negara Asia lainnya menjadi target. Salah satu negara yang menjadi tujuan ekspor sampah Eropa adalah Indonesia. Di satu sisi, Indonesia masih mengizinkan impor sampah. Berdasarkan Peraturan Menteri Perdagangan Nomor 31/M-DAG/PER/5/2016, Indonesia memperbolehkan perusahaan untuk melakukan impor limbah non bahan berbahaya dan beracun (B3) untuk keperluan bahan baku industri. Namun, sejak pertengahan tahun 2019 Indonesia menerima ratusan kontainer sampah yang tidak bisa didaur ulang dan mengandung B3 (Ihsanuddin, 2019) (Anggraini \& Puspita, 2019). Bahkan terdapat kasus di mana pengusaha tahu menggunakan plastik sebagai bahan bakar untuk pabrik tahu. Sampah plastik ini didapat para pengusaha dari pabrik kertas yang diduga mengimpor secara ilegal dari negara-negara maju seperti Amerika Serikat, Eropa, dan Australia (Tempo, 2019)

Gambar 2 Data Jumlah Volume Sampah yang Diekspor Uni Eropa ke Asia

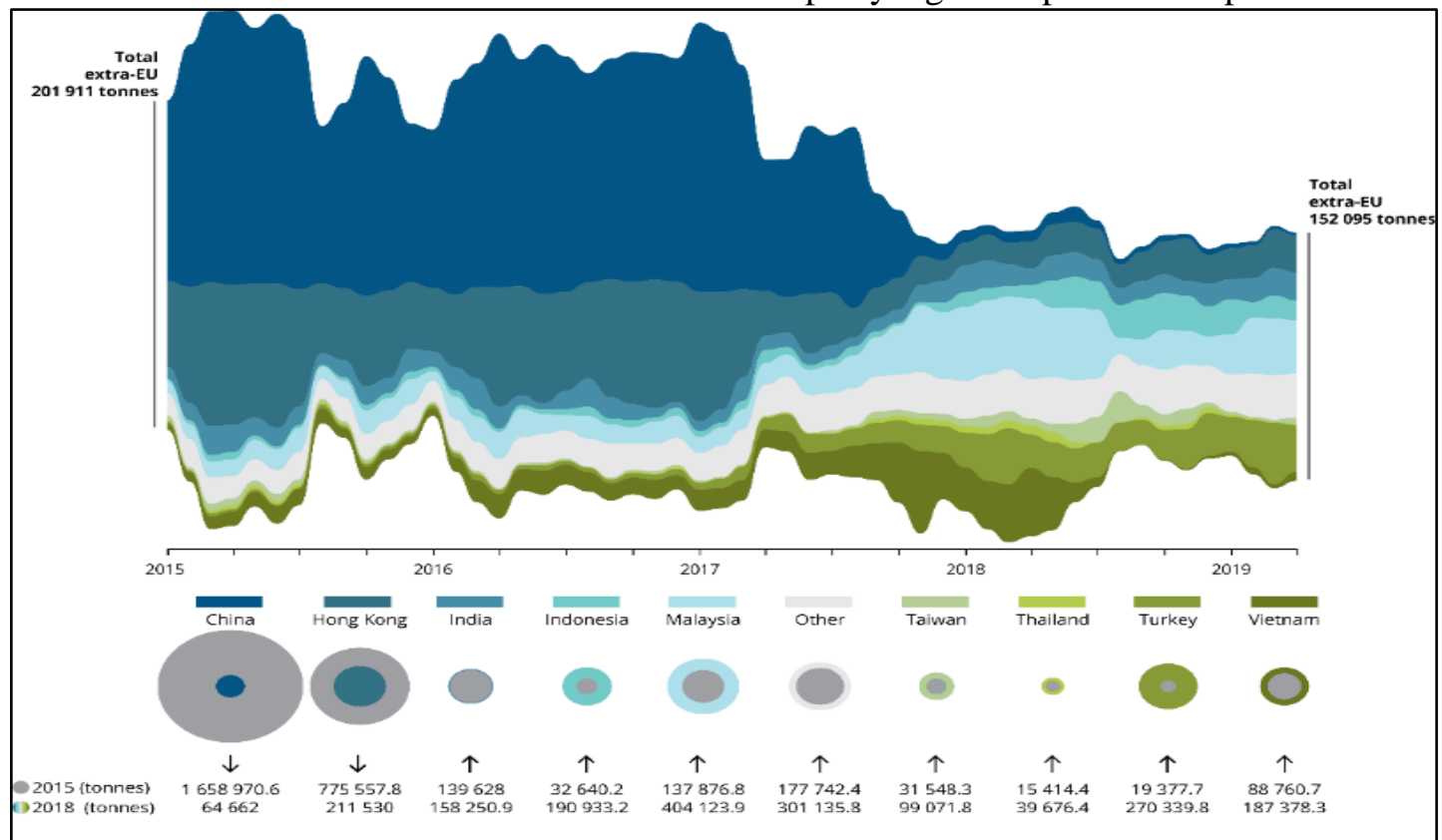

Sumber: European Environment Agency, 2019

Kebijakan ekspor sampah Uni Eropa ke Indonesia ini tidak sesuai dengan tujuan kerja sama internasional, khususnya Kyoto Protocol. Tujuan dibentuknya Kyoto Protocol adalah untuk bekerja sama mengurangi gas-gas antropogenik yang dihasilkan dari aktivitas manusia untuk mengurangi dampak pemanasan global. Standardisasi lingkungan yang dibuat hanya berfokus pada emisi karbon dari sektor industri dan transportasi sehingga mengabaikan 
sektor limbah padahal sektor limbah juga menjadi salah satu penyumbang emisi gas rumah kaca. Tulisan ini meninjau lebih lanjut bagaimana ekspor sampah oleh Uni Eropa ke Indonesia melanggar prinsip kerja sama internasional berbasis lingkungan.

\section{KERANGKA PEMIKIRAN}

Paradigma postmodernisme merupakan paradigma baru dalam ilmu hubungan internasional. Postmodernisme menolak bentuk empirisme dalam ortodoksi ilmu pengetahuan, yakni menolak pandangan bahwa ilmu pengetahuan hanya berdasarkan pengamatan terhadap fakta empiris. Postmodernisme menolak tiga hal yang menjadi dasar dalam paradigma positivisme, yakni kenyataan eksternal objektif, perbedaan antara subjek dan objek, serta ilmu sosial yang bebas nilai (Jackson \& Sørensen, 2013). Pendekatan genealogi dalam posmodernisme menyatakan bahwa pengetahuan yang ada selama ini bukanlah sesuatu yang netral dan bebas nilai. Pengetahuan merupakan sebuah pandangan perspektif tertentu terhadap suatu isu dalam konteks waktu dan tempat yang spesifik (Devetak, 2005). Subjek dari sebuah pengetahuan dibentuk oleh konteks sejarah dan politik tertentu dan dari perspektif sosial para peneliti sehingga cenderung condong kepada beberapa kepentingan. Hal inilah yang membuat para posmodernis menyatakan bahwa tidak ada kebenaran dan tidak ada fakta yang objektif.

Penulis menganalisis penelitian ini menggunakan konsep eco-imperialism. Dalam tulisan Lim Soomin dan Dr. Steven Shirley, eco-imperialism dijelaskan sebagai agenda lingkungan dari negara-negara maju (negara-negara Utara) sebagai bagian dari eksploitasi negara-negara berkembang (negara-negara Selatan). Eco-imperialism dilakukan dengan cara memaksakan apa yang menjadi standar nilai-nilai yang adil dan pantas dalam kebijakan terkait lingkungan menurut standar Barat. Hal ini kemudian membatasi pembangunan di negaranegara berkembang karena standar yang dibuat oleh negara-negara maju mengenai apa saja yang baik bagi lingkungan dan apa saja yang dapat berkontribusi dalam perubahan iklim yang disebabkan oleh manusia. Negara-negara maju dianggap melanggar kedaulatan negara-negara Selatan dengan memaksakan nilai-nilai yang mereka anut (Lim \& Shirley, 2009).

Metode penelitian yang dipakai dalam penelitian ini adalah metode penelitian kualitatif deskriptif. Data-data berasal dari studi pustaka atau dokumen dan literatur, kemudian data dijelaskan secara deskriptif. Dari data tersebut kemudian penulis akan melakukan analisis dan memberi argumentasi.

\section{HASIL DAN PEMBAHASAN}

\section{A. Ekspor Sampah sebagai Bentuk Moral Superiority Barat terhadap Negara Berkembang}

Penandatanganan Agenda 21 sebagai acuan pembangunan internasional sejak awal sudah memosisikan negara maju sebagai pemegang moral lingkungan sebagai norma baru dalam pembangunan internasional. Sejak awal, Agenda 21 sudah membagi kewajiban dan hak bagi negara-negara yang dikategorikan sebagai negara maju dan negara berkembang. Dalam Chapter 2 Agenda 21, disebutkan upaya-upaya yang harus dilakukan untuk mendorong pembangunan ramah lingkungan di negara-negara berkembang dan mendorong kebijakan domestik terkait. Salah satu bentuk kerja sama yang bisa dilakukan melalui sektor 
perdagangan. Bentuk moral superiority terkait dengan pemanasan global umumnya dan Agenda 21 khususnya terlihat jelas di sini.

Negara-negara Barat berusaha untuk menyebarkan gagasan bahwa pemanasan global merupakan permasalahan bersama. Oleh karena itu, negara-negara berkembang juga harus turut berpartisipasi dalam pemeliharaan lingkungan untuk mencegah pemanasan global yang berdampak terhadap perubahan iklim. Salah satu caranya adalah melalui upaya standardisasi di berbagai sektor termasuk perdagangan internasional melalui ISO 14000. Salah satu aspek yang dinilai dalam standarisasi ISO 14000 adalah sistem pengelolaan lingkungan. ISO 14000 merupakan sistem yang menilai suatu produk sejak pengadaan bahan baku sampai pembuangan produk yang habis masa pakainya (Hartati \& Yulia, 2008). Fungsi standarisasi ini adalah untuk memastikan bahwa kegiatan produksi barang yang diperjualbelikan dalam perdagangan internasional tidak merusak lingkungan dari aspek manapun.

Penerapan standardisasi ini mengakibatkan perbedaan atau gap antara negara-negara maju dengan negara-negara berkembang di bidang finansial, teknologi, dan sumber daya manusia. Sehingga muncul dikotomi produk perdagangan yang merugikan negara-negara berkembang. Produk dari negara maju yang memenuhi standar lingkungan dianggap lebih layak diperjualbelikan. Sikap ini merupakan salah satu bentuk eksploitasi negara-negara maju terhadap negara-negara selatan dengan menggunakan moral superiority di mana negara-negara maju merasa lebih berhak mengatur negara-negara selatan berdasarkan prinsip dan nilai mereka. Secara tidak langsung, negara-negara maju melanggar kedaulatan negara-negara selatan dengan prinsip dan nilai Barat (Lim \& Shirley, 2009).

Standardisasi lingkungan bisa menjadi justifikasi negara-negara maju untuk tetap monopoli industri terhadap negara-negara berkembang. Standardisasi akan membuat negaranegara maju terus memproduksi barang-barang yang sesuai dengan standar buatan mereka dan menjualnya ke negara-negara berkembang dengan doktrin bahwa barang tersebut diproduksi dengan etika lingkungan yang tinggi. Hal ini mengakibatkan barang-barang negara berkembang menjadi kalah saing dan akhirnya menghambat pertumbuhan ekonomi di negara-negara berkembang.

Dalam konteks ekspor sampah Uni Eropa ke Indonesia, standardisasi yang diberlakukan tidak mampu mengurangi volume produksi sampah plastik di Uni Eropa sendiri. Bahkan, volume sampah meningkat sebesar 8.6\% dalam rentang tahun 2013-2016 (Eurostat, 2019b). Di Uni Eropa sendiri tidak semua sampah bisa didaur ulang. Sampah yang tersebut bisa dimusnahkan dengan prosedur yang dinilai aman atau dikirim ke negara lain untuk diproses. 
Gambar 3 Data Material Sampah Uni Eropa Tahun 2016.

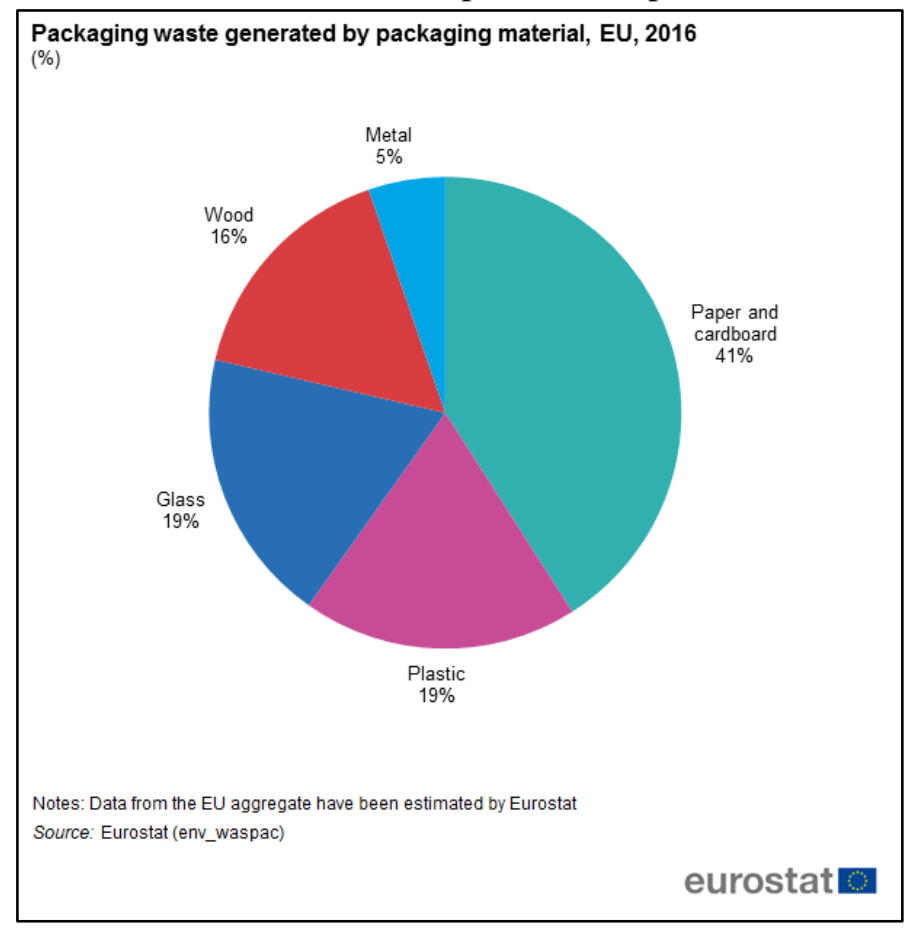

Sumber: Eurostat, 2019b

Untuk mengatasi permasalahan sampah tersebut Uni Eropa melakukan ekspor sampah dengan alasan dapat membawa manfaat ekonomi bagi kedua pihak. Sampah yang diekspor dapat digunakan oleh industri di Indonesia sebagai bahan baku. Hal ini merupakan bentuk eco-imperialism karena Uni Eropa dapat menggunakan bahan baku dari sumber daya yang terbaik sehingga produk yang dihasilkan pun kemungkinan besar dapat melewati standardisasi perdagangan yang mereka buat. Sementara itu, bahan baku yang digunakan industri di Indonesia merupakan bahan baku bekas dan bukan dengan kualitas terbaik. Bahkan dari bahan baku tersebut bisa jadi ada beberapa bagian yang tidak dapat dimanfaatkan dalam industri.

\section{B. Agenda Lingkungan Barat sebagai Bentuk Eksploitasi Negara-Negara Selatan}

Di Uni Eropa terdapat waste bierarchy dalam penanganan sampah, yakni pencegahan (prevention), daur ulang dan penggunaan ulang (recycle and reuse), dan meningkatkan pembuangan akhir dan pengawasan (improving final disposal and monitoring). Sampah yang tidak bisa didaur ulang harus dimusnahkan dengan aman dan penggunaan tempat pembuangan akhir menjadi pilihan paling terakhir dalam penanganan sampah (Eurostat, 2019c). Salah satu upaya yang dilakukan Uni Eropa dalam menangani permasalahan sampah adalah melakukan perdagangan sampah (waste trade) dengan negara-negara lain di Asia, termasuk Indonesia. Ekspor sampah dapat menguntungkan kedua pihak. Di satu sisi, Uni Eropa dapat mengurangi jumlah sampah yang ada di Uni Eropa. Di sisi lain, Indonesia bisa mendapatkan bahan baku yang dibutuhkan untuk keperluan industri. Persamaan antara kesepakatan perdagangan sampah ini adalah plastik merupakan material yang dilarang untuk dikirim ke negara tujuan. 
Plastik menjadi perhatian khusus dalam isu lingkungan karena secara alami plastik membutuhkan waktu ratusan tahun agar dapat terurai. Penanganan sampah plastik yang tidak sesuai standar dapat membahayakan lingkungan karena dapat menghasilkan racun dan emisi gas rumah kaca. Ekspor plastik untuk dihancurkan di luar negara Uni Eropa juga dilarang berdasarkan hukum Uni Eropa (European Environment Agency, 2019).

Namun dengan ditemukannya sampah plastik yang diekspor dari Uni Eropa ke Indonesia menunjukkan bahwa sistem penanganan Uni Eropa tidak berjalan sebagaimana seharusnya. Hal ini sangat bertentangan dengan sikap yang ditunjukkan oleh Uni Eropa dalam mendukung isu lingkungan, salah satunya dengan memberlakukan kebijakan plastik di wilayah Uni Eropa. Dalam hal ini, eksploitasi yang dilakukan Uni Eropa adalah eksploitasi lingkungan yang kemudian akan berdampak terhadap perekonomian masyarakat.

Plastik yang diekspor oleh Uni Eropa tidak akan bisa didaur ulang oleh Indonesia karena keterbatasan sumber daya manusia dan teknologi. Secara logika, Uni Eropa yang beranggotakan negara-negara maju masih tidak mampu untuk mendaur ulang sampah plastik mereka dan mengekspor sampah plastik ke negara berkembang seperti Indonesia dengan harapan bahwa sampah plastik tersebut dapat dimanfaatkan secara ekonomi dan didaur ulang adalah hal yang mustahil. Selain itu, kebijakan plastic strategy yang dikeluarkan oleh Uni Eropa untuk membatasi penggunaan plastik hanya berfokus pada produk plastik hasil industri seperti pipa PVC atau plastik dari barang elektronik. Uni Eropa belum mengatur tentang regulasi mengenai beberapa jenis sampah plastik sekali pakai (European Commission, 2019a)

Peningkatan jumlah sampah, khususnya sampah plastik, menimbulkan masalah bagi Indonesia. Pertama, jumlah sampah yang diterima Indonesia tidak sebanding dengan jumlah tenaga dan teknologi untuk mendaur ulang sampah-sampah tersebut. Sampah-sampah ini kemudian menumpuk dan akhirnya menjadi landfill waste atau sampah tempat pembuangan akhir. Landfill waste yang menumpuk akan mengalami dekomposisi dan menghasilkan andil gas yang terdiri dari metana $(\mathrm{CH} 4)$ dan karbon dioksida yang termasuk ke dalam gas rumah kaca. Bahkan metana dianggap 21 kali lebih berbahaya daripada karbon dioksida. Kurangnya teknologi profesional dalam pengelolaan sampah juga sering kali membuat sampah dikelola oleh pemulung yang tinggal di sekitar tempat pembuangan akhir (TPA). Untuk mengurangi volume sampah yang menumpuk, biasanya sampah-sampah tersebut dibakar atau dibuang ke sungai (Farizal, Aji, Rachman, Nasruddin, \& Mahlia, 2017). Pembakaran sampah, khususnya sampah plastik, sangat berbahaya bagi kesehatan dan lingkungan. Plastik yang dibakar dapat menghasilkan dioksin dan furan yang berdampak buruk untuk kesehatan. Selain itu, pembakaran plastik juga menghasilkan emisi karbon yang berperan dalam pemanasan global (The Jakarta Post, 2018).

Kedua, volume sampah yang meningkat akan menimbulkan masalah kebutuhan lahan untuk TPA. Salah satu contohnya adalah TPST Bantar Gebang yang merupakan tempat pembuangan sampah terpadu di Indonesia. Saat ini luas TPST Bantar Gebang adalah 110,3 hektar. Volume sampah domestik yang diterima TPST Bantar Gebang rata-rata mencapai 6.000 sampai 7.000 ton per hari (UPST DLH Jakarta, 2019). Daya tampung TPST Bantar Gebang adalah 49 juta ton dan pada tahun 2019, volume sampah yang ditampung di TPST Bantar Gebang sudah mencapai 29 juta ton. Kapasitas TPST Bantar Gebang diprediksi akan penuh pada tahun 2021 (detikNews, 2019). Volume sampah yang meningkat dapat 
menimbulkan masalah kesehatan bagi penduduk yang bermukim di sekitar TPST Bantar Gebang karena adanya pencemaran udara, air, dan tanah. Permasalahan lahan juga mengancam penduduk di sekitar TPST Bantar Gebang. Pemerintah akan memerlukan lahanlahan yang dimiliki penduduk di sekitar TPST Bantar Gebang sehingga diperlukan tindakan pembebasan lahan sehingga mengakibatkan penduduk di sekitar kehilangan aset mereka.

Ketiga, kurangnya fasilitas umum seperti akses pendidikan dan kesehatan mengakibatkan tingkat kesejahteraan penduduk di sekitar TPA terbilang rendah. Dalam studi yang dilakukan oleh Nila Kesuma dkk., tingkat pendidikan penduduk di sekitar TPST Bantar Gebang terbilang rendah. Hal ini dikarenakan kurangnya aksesibilitas penduduk ke sekolah dan rendahnya kesadaran penduduk akan pendidikan. Sebagian besar pendatang yang menetap di wilayah tersebut berprofesi sebagai pemulung yang menganggap bahwa anakanak mereka lebih baik bekerja memulung daripada sekolah karena bekerja dapat menghasilkan uang (Kesuma, Haryadi, \& Marsoyo, 2003).

\section{Ekspor Sampah Sebagai Pergeseran Tanggung Jawab Moral}

Kerja sama internasional yang berhubungan dengan lingkungan kebanyakan memberi beban lebih banyak kepada negara-negara maju. Hal ini dikarenakan negara-negara maju dianggap sebagai negara industri yang telah mengeksploitasi kekayaan bumi lebih banyak dan lebih lama dari negara-negara berkembang. Dari data yang dikeluarkan Uni Eropa, pada tahun 2017 emisi karbon di Uni Eropa mengalami penurunan, namun sebanyak 54 persen emisi karbon yang dihasilkan berasal dari pembakaran bahan bakar fosil untuk kepentingan selain transportasi (Eurostat, 2019a)

Pembatasan emisi karbon berfokus pada emisi hasil industri karena industri merupakan penghasil gas rumah kaca terbesar. Namun, pembatasan karbon tidak berdampak pada pengurangan sampah di Uni Eropa. Pada tahun 2016, jumlah sampah di Uni Eropa mencapai 2.538 juta ton. Dari jumlah tersebut, sebanyak $53.2 \%$ sampah dimanfaatkan kembali dan sisanya sebanyak 46.8\% menjadi landfill waste, dibakar, atau dimusnahkan dengan cara lain (Eurostat, 2019b).

Gambar 4 Sumber Sampah di Uni Eropa pada Tahun 2016

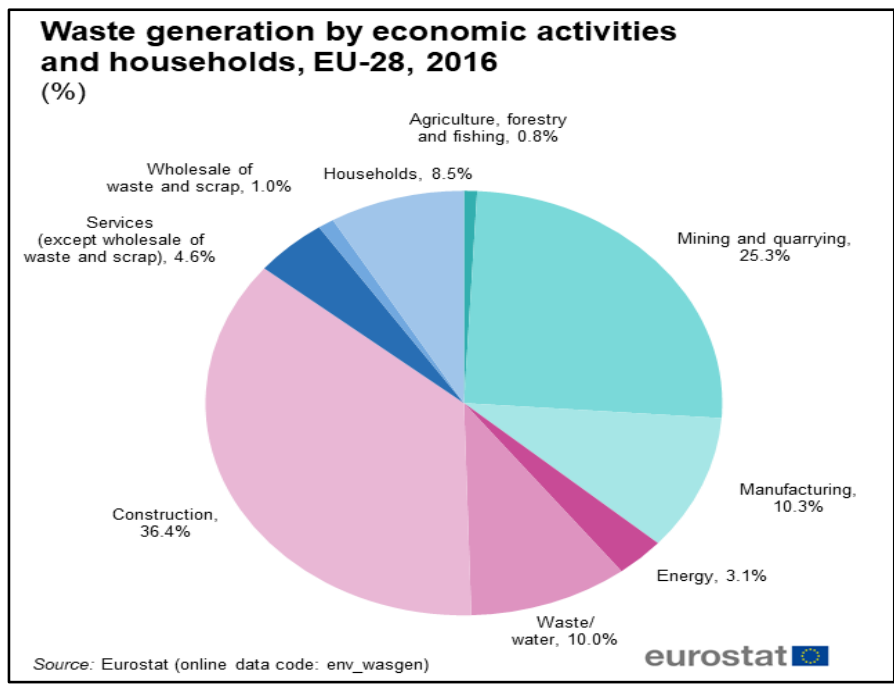

Sumber: Eurostat, 2019b 
Di sisi lain, Indonesia merupakan negara dengan penduduk terbanyak keempat di dunia. Berdasarkan data Badan Pusat Statistik, pada tahun 2018 jumlah penduduk Indonesia mencapai 237.641.300 jiwa. Dengan jumlah penduduk yang banyak, Indonesia memerlukan sektor industri untuk memenuhi kebutuhan masyarakatnya. Industri yang ada di Indonesia tidak hanya terdiri dari industri besar dengan pabrik yang besar, namun ada juga industri kecil dan menengah yang turut berperan dalam perekonomian Indonesia. Berdasarkan Peraturan Kementerian Perindustrian Nomor 64 Tahun 2016, industri kecil merupakan industri yang memiliki investasi senilai kurang dari 1 milyar rupiah. Sementara industri menengah merupakan industri yang memiliki nilai investasi kurang dari 1 milyar rupiah atau paling banyak 15 milyar rupiah.

Setiap industri memerlukan bahan-bahan, baik untuk bahan baku maupun sebagai bahan bakar. Kesulitan untuk mendapatkan bahan baku menjadi pertimbangan Indonesia dalam melegalkan impor sampah sebagai sumber bahan baku dalam industri, terutama industri kertas. Industri kertas memerlukan sampah kertas bekas untuk kemudian diolah kembali menjadi kertas baru. Namun, pada tahun 2019 Indonesia menerima ratusan kontainer sampah dari berbagai negara dan di antara kontainer tersebut terdapat sampah dari beberapa negara Uni Eropa. Kontainer tersebut tidak hanya berisi sampah scrap yang dapat didaur ulang tetapi juga terdapat sampah plastik yang tidak dapat didaur ulang (CNBC Indonesia, 2019)

Penemuan ini menunjukkan bahwa Uni Eropa gagal dalam memainkan peran dalam pemeliharaan lingkungan seperti yang selama ini diberitakan. Berdasarkan peraturan Uni Eropa dalam penanganan ekspor sampah, Uni Eropa harus memastikan bahwa sampah yang diekspor, baik ke negara-negara Uni Eropa maupun negara tujuan lainnya, tidak mengandung bahan berbahaya dan beracun (European Commission, 2019b). Selain itu, ekspor sampah B3 dari Uni Eropa merupakan pelanggaran Artikel 2 dan 6 dari Kyoto Protocol. Dalam Artikel 6 disebutkan bahwa negara-negara anggota dapat bekerja sama dengan tujuan mengurangi emisi gas rumah kaca. Ada beberapa hal yang seharusnya menjadi perhatian Uni Eropa dalam mengekspor sampah ke Indonesia. Pertama, volume sampah domestik di Indonesia sendiri sudah sangat banyak. Berdasarkan Laporan Statistik Lingkungan Hidup Indonesia pada tahun 2018, produksi sampah Indonesia mencapai 65 juta ton setahun. Kedua, teknologi dan sumber daya manusia yang dimiliki Indonesia dalam pengelolaan sampah masih minim. Sebagian besar sampah Indonesia merupakan sampah rumah tangga, namun penanganannya selama ini masih menggunakan cara membakar sampah (Badan Pusat Statistik, 2018).

Ekspor sampah yang dilakukan oleh Uni Eropa menunjukkan adanya upaya pergeseran tanggung jawab mengenai masalah lingkungan. Jumlah penduduk Indonesia yang banyak turut berperan dalam jumlah produksi sampah di Indonesia. Berdasarkan data Climate Transparency, emisi gas rumah kaca di Indonesia paling banyak dihasilkan oleh limbah. Hal ini tidak mengherankan karena sebagian besar produksi sampah Indonesia berasal dari sektor rumah tangga. Sampah ini kemudian tidak bisa didaur ulang sehingga akan berakhir menjadi landfill waste. Seperti yang dijelaskan di bagian sebelumnya, landfill waste yang tidak diolah akan mengalami dikomposi dan menghasilkan partikel gas rumah kaca seperti metana dan karbon dioksida. 
Ekspor sampah juga menjadi pergeseran tanggung jawab lingkungan dalam pengurangan emisi karbon. Indonesia merupakan negara padat penduduk yang bergantung pada industri untuk memenuhi kebutuhan masyarakatnya. Dengan melakukan ekspor sampah, Uni Eropa membiarkan Indonesia mengalami peningkatan karbon dioksida, baik dari sektor industri maupun dari sektor rumah tangga. Apalagi Indonesia belum memiliki kebijakan ketat mengenai permasalahan sampah.

Mekanisme yang diatur dalam kerja sama internasional berbasis lingkungan seperti Kyoto Protocol dan Basel Convention juga merugikan Indonesia karena dua hal. Pertama, kerja sama internasional umumnya hanya berfokus pada emisi dalam jumlah besar seperti emisi dan limbah industri. Kedua, kerja sama internasional berfokus pada upaya-upaya negara maju dalam pembatasan pencemar. Namun, tidak ada mekanisme yang mengikat bagi negaranegara maju tersebut apabila dalam pelaksanaannya, negara-negara maju melakukan pelanggaran seperti yang dilakukan oleh Uni Eropa ke Indonesia melalui ekspor sampahnya. Kerja sama internasional tersebut juga tidak memberikan banyak pilihan bagi Indonesia sebagai negara berkembang untuk bersikap sehingga Indonesia terpaksa menerima mekanisme yang sudah disepakati tersebut.

\section{KESIMPULAN}

Permasalahan lingkungan merupakan salah satu isu yang menjadi perhatian dunia saat ini. Berbagai kerja sama multilateral dilakukan untuk mewujudkan pembangunan global yang ramah lingkungan. Uni Eropa merupakan salah satu partisipan dalam berbagai forum internasional tersebut. Namun, kebijakan ekspor sampah yang dilakukan oleh Uni Eropa ke Indonesia bertentangan dengan berbagai kebijakan lingkungan yang ada. Kebijakan ekspor sampah oleh Uni Eropa bisa dianggap sebagai suatu bentuk eco-imperialism dimana Uni Eropa menjadi bagian dari negara-negara maju dalam menggunakan agenda lingkungan untuk memaksakan nilai moral mereka yang didorong oleh moral superiority negara-negara maju sebagai bagian dari eksploitasi negara-negara berkembang, termasuk Indonesia.

Dalam konteks ekspor sampah, moral superiority yang dibentuk adalah bahwa pemanasan global merupakan permasalahan bersama sehingga diperlukan kerja sama antar negara untuk mencegah pemanasan global. Salah satu upaya yang dilakukan adalah membentuk standardisasi lingkungan, termasuk dalam hal perdagangan. Standardisasi ini menjadi justifikasi monopoli ekonomi yang dilakukan oleh Uni Eropa. Pada kenyataannya, standarisasi yang diterapkan tidak mampu mengurangi volume sampah, khususnya sampah kemasan plastik, di Eropa.

Ekspor sampah juga menjadi bentuk eksploitasi terhadap lingkungan di Indonesia. Dengan meningkatnya jumlah sampah yang tidak bisa didaur ulang, maka kemungkinan besar sampah tersebut akan menjadi landfill waste yang dapat menghasilkan gas emisi rumah kaca. Permasalahan lainnya yang ditimbulkan oleh peningkatan volume sampah plastik adalah muncul permasalahan lahan dan juga berkaitan dengan tingkat kesejahteraan masyarakat di sekitar TPA. Pada akhirnya, kerja sama internasional berbasis lingkungan merupakan salah satu upaya pergeseran tanggung jawab moral. Hal ini dapat dilihat bahwa kerja sama internasional yang ada sangat berfokus pada upaya-upaya yang dilakukan oleh negara-negara maju dalam mencapai target yang ditentukan oleh kerja sama internasional. Namun, kerja 
sama internasional yang ada saat ini tidak memiliki sanksi yang tegas terhadap pelanggaran lingkungan yang dilakukan oleh negara-negara maju, seperti ekspor sampah B3 yang dilakukan oleh Uni Eropa ke Indonesia.

\section{DAFTAR PUSTAKA}

Anggraini, \& Puspita, A. (2019). Di Balik Impor Sampah Plastik Berkedok Bahan Baku Industri. Retrieved from Kompas website: https://www.kompas.com/tren/read/2019/09/20/125000465/di-balik-imporsampah-plastik-berkedok-bahan-baku-industri? page $=$ all

Badan Pusat Statistik. (2018). Statistik Lingkungan Hidup Indonesia.

CNBC Indonesia. (2019). Kenapa Indonesia Impor Sampah? Retrieved from CNBC Indonesia website: https://www.cnbcindonesia.com/news/20190706182210-483157/kenapa-indonesia-impor-sampah

detikNews. (2019). Bantargebang Menunggu Tumbang. Retrieved from Detik.com website: https://news.detik.com/x/detail/investigasi/20191120/Bantargebang-MenungguTumbang/

Devetak, R. (2005). Postmodernism. In Theories of International Relations. New York: Palgrave Macmillan.

European Commission. (2019a). Single-use Plastics. Retrieved from European Commission website: https://ec.europa.eu/environment/waste/plastic_waste.htm

European Commission. (2019b). Waste shipment. Retrieved from European Commission website: https://ec.europa.eu/trade/import-and-export-rules/export-from-eu/wasteshipment/

European Environment Agency. (2019). The plastic waste trade in the circular economy. Retrieved from European Environment Agency website: https:/ / www.eea.europa.eu/publications/the-plastic-waste-trade-in/the-plastic-wastetrade-in

Eurostat. (2019a). Greenhouse gas emission statistics - emission inventories. Retrieved from Eurostat website: https://ec.europa.eu/eurostat/statisticsexplained/index.php?title=Greenhouse_gas_emission_statistics

Eurostat. (2019b). Packaging Waste Statistics. Retrieved from Eurostat website: https://ec.europa.eu/eurostat/statistics-

explained/index.php/Packaging_waste_statistics\#Generation_and_recycling_per_inh abitant

Eurostat. (2019c). Waste Statistics. Retrieved from Eurostat website: https://ec.europa.eu/eurostat/statistics-

explained/index.php/Waste_statistics\#Total_waste_generation

Farizal, F., Aji, R., Rachman, A., Nasruddin, N., \& Mahlia, T. M. I. (2017). Indonesia's Municipal Waste 3R and Waste to Energy Programs. Makara Journal of Technology, 153159.

Hartati, \& Yulia, A. (2008). Perdagangan Bebas dan Lingkungan Hidup dalam Perspektif Posmodernisme (Melihat Kasus Penerapan Standardisasi Lingkungan). SPEKTRUM: Jurnal Imu Politik Hubungan Internasional, 38-54.

Ihsanuddin. (2019). "Sampah Impor” Masuk ke Indonesia, dari Popok, Bekas Alat Infus, hingga Obat. Retrieved from Kompas website: https://nasional.kompas.com/read/2019/08/28/06040071/-sampah-impor-masukke-indonesia-dari-popok-bekas-alat-infus-hingga-obat 
Jackson, R., \& Sørensen, G. (2013). Introduction to International Relations: Theories and Approaches. Oxford: Oxford University Press.

Kesuma, N., Haryadi, H., \& Marsoyo, A. (2003). Perubahan Fisik Keruangan dan Sosial Ekonomi Masyarakat di Kawasan Sekitar Tempat Pembuangan Akhir Sampah Bantargebang Kota Bekasi. Manusia Dan Lingkungan, 74-82.

Lee, Y. N. (2018). The world is scrambling now that China is refusing to be a trash dumping ground. Retrieved from CNBC website: https://www.cnbc.com/2018/04/16/climate-change-china-bans-import-of-foreignwaste-to-stop-pollution.html

Lim, S., \& Shirley, S. (2009). Eco-Imperialism: The Global North's Weapon of Mass Intervention. Journal of Alternative Perspectives in the Social Sciences, 846-860.

Ritchie, H., \& Roser, M. (2019). $\mathrm{CO}_{2}$ and Greenhouse Gas Emissions. Retrieved from Our World in Data website: https://ourworldindata.org/co2-and-other-greenhouse-gasemissions

Tempo. (2019). Masuk Sampah Keluar Racun. Retrieved from Tempo website: https://koran.tempo.co/read/cover-story/447663/masuk-sampah-keluar-racun

The Jakarta Post. (2018). Burning plastic waste harmful to health. Retrieved from The Jakarta Post website: https://www.thejakartapost.com/life/2018/03/31/burningplastic-waste-harmful-to-health.html

UNFCCC. (1992). United Nations Framework Convention on Climate Change. UNFCCC. Retrieved from https://unfccc.int/resource/docs/convkp/conveng.pdf

UNFCCC. (2019). What is the Kyoto Protocol? Retrieved from United Nations Framework Convention on Climate Change website: https://unfccc.int/kyoto_protocol

UPST DLH Jakarta. (2019). Tempat Pengelolaan Sampah Terpadu Bantargebang. Retrieved from Unit Pengelolaan Sampah Terpadu Dinas Lingkungan Hidup Jakarta website: http://upst.dlh.jakarta.go.id/tpst/index 